\title{
Representasi Karakter Autis Dalam Film Dancing in The Rain
}

Sarah Novita Diah

Sri Wijayanti

\author{
| Program Studi Ilmu Komunikasi, Fakultas Humaniora dan Bisnis, Universitas \\ Pembangunan Jaya, Bisa dihubungi melalui email: sarah.novitadiah@student.upj.ac.id \\ | Program Studi llmu Komunikasi, Fakultas Humaniora dan Bisnis, Universitas \\ Pembangunan Jaya. Bisa dihubungi melalui email: sri.wijayanti@upj.ac.id
}

\section{ABSTRAK}

This research Focuses on how Indonesian movie portrays an autistic character. The Importance point of this research is because there is some misunderstanding around the society about people with autism. Dancing in The Rain is the most recent movie in Indonesia that held on 2018 and portrays about people with autism. That's why this movie as an object for this research. This research used semiotic analysis by Roland Barthes, to giving enlightenment to the society about people with autism. This research finds that autistic character still used as a commodity to get sympathy from the audience. The interesting result that has been found for this movie, that this movie describe how people with autism can improve their social development as long as they grow up and get an autistic therapy.

Keywords: Autistic, semiotics, analysis, representation, character, Film/movie

\section{Pendahuluan}

Fenomena diskriminasi dan stigmatisasi dapat dialami oleh siapa saja dan di mana saja. Fenomena tersebut juga terjadi atau dialami oleh para penyandang autis di berbagai belahan dunia termasuk di Indonesia.

Diskriminasi dan stigma terhadap penyandang autis di Indonesia bukanlah hal baru. Para penyandang autis masih sering mendapatkan diskriminasi dari masyarakat. Bahkan sering kali penyandang autis dianggap sebagai gangguan bagi lingkungan masyarakat. Kasus sikap diskriminasi, intoleransi, pelecehan fisik sampai stigmatisasi sering terjadi atau dialami oleh para penyandang autis di Indonesia (Kirnandita, 2017).

Berdasarkan hasil survei yang dilakukan secara online faktanya masyarakat Indonesia belum memahami betul tentang apa itu sindrom autisme. Maka dari itu banyaknya stigma tentang penyandang autis di masyarakat menjadi permasalahan tersendiri, terutama di Indonesia (Wijayanti, 2019).

Salah satu contoh kasus diskriminasi yang sering terjadi yaitu penyebutan 'kekurangan' yang dimiliki seseorang. Seperti sebutan 'autis' atau 'idiot' untuk orang-orang yang memiliki keterbelakangan mental. Menurut Yayasan Autisma Indonesia penggunaan kata-kata tersebut untuk kaum tunagrahita, sering kali digunakan untuk menunjukkan sikap intoleransi dengan mengejek atau menggambarkan perilaku 
seseorang (Ralie, 2019).

Menurut Budhiman ketua Yayasan Autisma Indonesia, ia masih sering menemukan tindakan perundungan terhadap penyandang autis. Beliau menyesalkan kasus perundungan tersebut kurang mendapatkan perhatian dari banyak pihak (Sihombing, 2019). Setelah kasus perundungan yang di alami oleh penyandang autis, muncul pula stigma masyarakat terhadap penyandang autis dan keluarganya menjadi fenomena permasalahan sosial lainnya.

Stigma masyarakat membuat orang tua ataupun keluarga penyandang autis sering kali merasakan penolakan, perasaan takut, sedih, marah dan mengisolasi diri dari lingkungan sosial (Kurniadi dkk, 2019).

Banyak masyarakat Indonesia menganggap autis merupakan sebuah penyakit yang menular, tidak dapat diobati dan sama dengan gangguan kejiwaan. Tidak sedikit juga dari keluarga dan masyarakat yang menganggap bahwa autis merupakan aib untuk keluarga dan dapat berdampak negatif pada identitas sosial anak, keluarga dan juga lingkungan (Wijayanti, 2019). Selain stigmatisasi tersebut, keadaan penyandang autis di lingkungan sosial masyarakat juga masih cukup memprihatinkan..

Menurut WHO (World Health Organization) diperkirakan setidaknya ada satu dari 160 anak di dunia yang mengalami Autism Spectrum Disorder (ASD). Berdasarkan studi epidemiologis yang telah dilakukan selama 50 tahun terakhir menunjukkan angka yang terus menerus meningkat secara global (WHO, 2019).

Sejauh ini di Indonesia sendiri, belum ada data resmi yang menjelaskan tentang jumlah penyandang autis di Indonesia. Akan tetapi menurut data yang dikeluarkan oleh Incidence dan Prevalence ASD (Autism Spectrum Disorder) di Indonesia sendiri terdapat setidaknya 2 kasus penyandang autis baru dari 1000 penduduk di setiap tahunnya dan 10 kasus lama autis per 1000 penduduk (Kemenpppa, 2018).

Jika kita melihat bagaimana kondisi Indonesia menangani para penyandang autis yang merupakan warga negaranya, saat ini memang sudah jauh berbeda dibandingkan dengan 20 tahun yang lalu. Meski sudah lebih baik, ia masih sangat jauh dari kebutuhan akan hak-hak sebagaimana diatur dalam perlindungan undangundang. Hal tersebut menunjukkan masih kurangnya perhatian dan pemahaman masyarakat dan pemerintah tentang hak-hak penyandang autis sebagai anggota dalam masyarakat (Sihombing, 2019).

Maka lingkungan sosial masyarakat memerlukan peran dari pihak-pihak yang memang dapat memberikan informasi ataupun eduaksi kepada masyarakat. Salah satu pihak yang sangat berperan aktif dalam menyebarkan informasi untuk masyarakat adalah media. Media menjadi salah satu faktor penting yang digunakan banyak pihak untuk menyebarkan sebuah informasi. Salah satu jenis media massa yang dapat digunakan untuk menyampaikan stigma positif kepada masyarakat adalah melalui film.

Alasan mengapa film dapat menyampaikan pesan kepada khalayak adalah karena film merupakan representasi yang menghasilkan sebuah realitas yang sengaja dibentuk untuk memberikan gambaran melalui kode, mitos ataupun ideologi. Pada beberapa sisi penggunaan 
film yaitu sebagai media massa dikemas untuk menyoroti kejadian, isu atau aktivitas yang ada di masyarakat (Toni, 2015).

Maka sebagai media yang dapat mempersuasi dan menyebarkan informasi kepada masyarakat, film dapat digunakan dalam menyebarkan informasi terkait penyandang autis. Hal ini seperti yang dikatakan oleh Direktur Eksekutif Remotivi Roy Thaniago, bahwa media memiliki peran dalam membentuk makna tentang disabilitas di mata masyarakat. Film yang menjadi bagian dari media massa juga dapat menyampaikan pesan secara umum atau universal yang tidak ditujukan kepada suatu kelompok masyarakat tertentu (Ghassani, 2019).

Maka peran media masa sangat penting dalam membentuk lingkungan sosial yang baik untuk para kaum disabilitas termasuk para penyandang autis (Ultimagz, 2019). Terlebih lagi dengan kelebihan film sebagai media massa yang dapat menjadi media edukasi untuk masyarakat umum.

Akan tetapi dalam menyampaikan informasi ataupun edukasi yang sukses melalui film terhadap komponen-komponen penting yang harus diperhatikan. Salah satunya adalah dalam membentuk sebuah karakter/ tokoh yang dapat menyampaikan infromasi dengan baik sesuai dengan apa yang ingin disampaikan melalui film tersebut (Forno, 2015).

Karakter atau tokoh dalam sebuah film mempunyai peran penting untuk menyampaikan sebuah infromasi. Di mana karakter atau tokoh dapat menjadi gambaran atau perwujudan perilaku manusia yang ada di lingkungan masyarakat melalui sebuah film.

Di Indonesia sendiri film dengan tema penyandang autis bukanlah hal baru. Terdapat beberapa contoh film dengan tema autisme yang menampilkan secara jelas sejak awal hingga akhir melalui tokoh/ karakter autis. Seperti I'm Star karya Damien Demantra pada tahun 2013. Kemudian film Malaikat Kecil karya sutradara Inggrid Rhemanty pada tahun 2015, film My Idiot Brother karya Alyandra pada tahun 2014 dan lain sebagainya (Hardian, 2018). Akan tetapi dalam setiap pembuatan film pastinya mempunyai penggambaran karakter/ tokoh yang cukup berbeda satu sama lain (Eka, 2013).

Sedangkan pada tahun 2018 terdapat satu lagi karya film dengan tema autisme yang dibuat oleh produser Rudi Aryanto yang ditulis oleh Sukhdev Singh dan Tisa T.S yaitu 'Dancing in The Rain'. Film 'Dancing in The Rain' ini merupakan kisah seorang anak bernama Banyu (Dimas Anggara) dengan keterbelakangan mental atau autis yang hidup di tengah masyarakat yang antipati dan belum perduli dengan sosok seperti Banyu.

Film Dancing in The Rain mendapatkan apresiasi dari masyarakat, salah satunya dari Forum Komunikasi Orang Tua Anak Spesial Indonesia (Forkasi) daerah Sumatera Barat. Dikarenakan telah menginformasikan pesanpesan penting tentang penyandang autis terutama di Indonesia. Forkasi menyatakan bahwa film Dancing in The Rain dapat mengubah stigma dan pandangan masyarakat terhadap penyandang autis (Wahyudi, 2018).

Tisa TS selaku penulis naskah film menyatakan bahwa tujuan dari pembuatan film Dancing in The Rain yang ingin menyampaikan pesan bahwa tidak ada orang yang sempurna dan kita semua dikelilingi oleh orang-orang tidak sempurna itu. 
Film Dancing in The Rain juga ingin menyampaikan kepada masyarakat untuk lebih menghargai ketidaksempurnaan dan membagikan kebahagiaan kita kepada orang lain (Sekhu, 2018).

Penelitian terkait karakter autis dalam sebuah film sebelumnya pernah dilakukan oleh Elfira Rose Ardiansari pada tahun 2014. Penelitian yang berjudul 'Representasi Toleransi Dalam Film My Name Is Khan' dengan teknik analisis data semiotika terhadap tokoh Rizwan Khan. Selain itu ada juga penelitian yang dilakukan oleh Nessa Afrilin pada tahun 2018 dengan judul 'Analisis Naratif Karakter Autis Dalam Film Malaikat Kecil'. Kemudian penelitian selanjutnya dilakukan oleh Santika Heni pada tahun 2018 dengan judul 'Romatic Relationship Pada Penderita Autisme'.

Dari beberapa penelitian terdahulu terkait karakter autis dan beberapa penjelasan terkait film serupa menunjukkan bahwa setiap penggambaran karakter penyandang autis terkesan terlalu positif yang berlebihan. Maka dari penjelasan di atas penelitian ini mengkritisi bagaimana representasi karakter autis dalam film Dancing in The Rain. Hal tersebut untuk melihat seberapa tepat penggambaran karakter penyandang autis sesuai dengan realitas ataupun kenyataan.

Perbedaan antara penelitian yang dilakukan dengan penelitian terdahulu adalah penelitian ini tidak hanya berfokus pada bagaimana penggambaran karakter autis dalam film Dancing in The Rain akan tetapi juga penelitian ini akan mengkritisi terkait bagaimana penggambaran karakter yang terdapat dalam film tersebut. Maka dari itu hasil yang akan didapatkan dalam penelitian ini tentunya juga akan berbeda dengan hasil yang didapatkan pada penelitian sebelumnya terkait film dengan tema autisme yang hanya menjabarkan seperti apa penggambaran karakter autis tersebut.

Penelitian ini merupakan penelitian kualitatif, di mana hasil dari penelitian nantinya akan berbentuk deskripsi dari data yang didapatkan. Penelitian ini nantinya akan menggunakan analisis semiotika milik Roland Barthes sebagai teknik dalam pengumpulan data. Alasan penggunaan analisis semiotika Roland Barthes dikarenakan peneliti ingin mendapatkan hasil berupa interpretasi dan makna dari tanda-tanda sebagai hasil representasi karakter autis dalam film Dancing in The Rain. Selain itu peneliti juga ingin mengkritisi kemungkinan pada mitos-mitos yang muncul pada film.

\section{Kajian Pustaka}

Representasi

Representasi secara sederhana dapat diartikan sebagai gambaran mengenai suatu hal dalam kehidupan yang digambarkan melalui suatu bentuk media (Permatasari \& Yenny, 2019). Menurut John Fiske, representasi terbagi ke dalam tiga proses.

Proses pertama adalah peristiwa di mana akan ditandakan pada saat kita menganggap dan mengkonstuksi sebuah peristiwa tersebut sebagai sebuah bentuk realitas. Proses kedua adalah di saat kita memandang suatu realitas dan selanjutnya kita mempertanyakan bagaimana realitas itu digambarkan. Kemudian proses ketiga yaitu di mana kode-kode representasi saling dihubungkan dan diorganisasikan ke dalam kelas 
sosial, kepercayaan dominan dan lain sebagainya yang memang terdapat dalam masyarakat (Saragih, 2019).

Konsep representasi itu sendiri dianggap sebagai proses yang dinamis dan terus berkembang seiring dengan kemampuan intelektual dan kebutuhan lingkungan akan sebuah tanda. Sama hal nya seperti manusia representasi selalu berubah dan berkembang (Putri, 2018).

\section{Analisis Semiotika}

Semiotika menurut Barthes dalam Irfandy (2009) merupakan ilmu atau metode untuk menganalisis yang digunakan dalam pengkajian data. Dengan tujuan untuk mengkaji bagaimana kemanusiaan (humanity) dalam memaknai (to signify) berbagai hal (things) dan mengkomunikasikan (to communicate).

Pada model analisisnya Barthes menegaskan ke dalam kosep denotasi dan konotasi sebagai inti dari bentuk model analisisnya. Di mana model tersebut juga lebih populer disebut sebagai two order of signification (signifikasi dua tahap) (Irfandy, 2019).

Dalam definisinya makna denotasi merupakan sistem signifikasi tingkat pertama dengan ketertutupan makna. Dalam analisisnya makna denotasi bersifat secara langsung dan khusus yang terdapat pada suatu tanda. Makna konotasi Barthes merujuk pada penggambaran interaksi yang terjadi saat tanda bertemu berkaitan dengan perasaan, emosi dan juga nilai-nilai kebudayaan. Pada intinya makna konotasi merupakan makna yang subjektif atau intersubjektif (Avrila, 2019).
Sedangkan mitos merupakan cerita atau narasi untuk mengekspresikan lapisan dalam eksistensi manusia dan sering kali irasional atau tidak masuk akal. Akan tetapi mitos yang dimaksud dalam analisis semiotika Barthes digunakan tidak sepenuhnya sama dengan definisinya secara tradisional. Di mana mitos berfungsi untuk mengungkap dan melakukan pembenaran terhadap nilai-nilai dominan yang berlaku pada periode tertentu. Dalam mitos nantinya juga terdapat pola yaitu penanda, pertanda dan tanda (Putra, 2019).

\section{Film}

Film merupakan salah satu media elektronik yang termasuk ke dalam bagian dari media massa. Film bisa diartikan sebagai gambar yang diproyeksikan ke layar dengan kecepatan tertentu, dijadikan dalam bentuk urutan atau tingkatan yang berjalan beriringan secara terus menerus sehingga menggambarkan pergerakan yang tampak normal (Rochmawati, 2016).

Film merupakan salah satu bentuk komunikasi massa yang pada dasarnya tidak hanya dijadikan sebagai sarana hiburan, akan tetapi juga bisa dijadikan sebagai sarana pendidikan. Film menjadi karya seni yang produksinya merupakan ranah kreatif dan memenuhi imajinasi orang-orang dengan tujuan untuk memperoleh estetika atau keindahan (Ardianto, 2012).

Film menjadi media untuk orang-orang menambah wawasan mereka terkait banyak hal. Hal tersebut membuat banyak orang berlombalomba menjadikan film sebagai media untuk memikat orang. Edukasi melalui film bisa 
digunakan sebagai media pembelajaran dalam bentuk pendidikan literasi. Minat membaca yang rendah di Indonesia dapat dialihkan pada minat menonton film sebagai media informasi. Hal tersebut dikarenakan film dapat menjadi media komunikasi nonpersonal yang bisa menarik minat dan perhatian sebagai media untuk belajar (Hosnan, 2014).

Dalam membuat film yang bagus dan bisa menyampaikan pesan dengan baik kepada penonton banyak hal yang perlu diperhatikan. Salah satunya adalah pada proses teknik pengambilan gambar dalam sebuah film. Menurut Sanni dkk (2016) dalam penelitiannya ada teknik pengambilan gambar yang perlu diaplikasikan dalam pembuatan film.

\section{Tokoh}

Tokoh dalam sebuah cerita merupakan orang diperkenalkan atau ditampilkan melalui suatu rangkaian narasi yang ditafsirkan oleh pembaca/ penonton berdasarkan kualitas moral dan kecenderungan tertentu. Dalam sebuah film tokoh memiliki posisi yang sangat strategis terlebih lagi dalam membawakan pesan, amanat, moral atau sesuatu yang memang ingin disampaikan dalam sebuah film (Muthmainah, 2020).

Dalam sebuah pembuatan film karakter atau tokoh terdiri dari berbagai jenis. Pertama karakter yang berdasarkan segi peranan dan tingkat kepentingannya dalam sebuah film diartikan sebagai tokoh utama dan tokoh tambahan. Kemudian karakter berdasarkan fungsi penampilan tokoh dalam film, biasanya terbagi atas protagonis atau antagonis (Hasanah, 2019).

\section{Autis}

Autisme merupakan kondisi gangguan perilaku yang menyerang seseorang dan mempengaruhi mereka dalam berkomunikasi, bersosialisasi dan mengurus diri mereka. Hal tersebut juga sesuai dengan yang dijelaskan oleh Medise bahwa autisme bukalah sebuah bentuk penyakiit. Melainkan autisme merupakan gangguan pada perilaku seseorang (Auticare.id, 2019).

Menurut buku elektronik yang dikeluarkan oleh organisasi Autism Europe pada tahun 2019, umumnya ada beberapa tanda yang bisa dilihat apakah seseorang mengalami autisme. Jika dikelompokkan masuk ke dalam tiga kelompok tanda yaitu komunikasi, bersosialisasi, minat dan sikap.

Seseorang yang terlahir sebagai penyandang autis, terkadang sering kali mengalami gangguan pada fisik. Salah satunya adalah pada kesulitan koordinasi anggota gerak tubuh. Kesulitan koordinasi ini termasuk juga di dalamnya kekuatan pada otot, mobilitas dan keterampilan pada motorik. Maka dari itu penting sekali sejak dini penyandang autis menerima terapi khusus untuk memperbaiki motorik tubuh. Dikarenakan jika tidak dilakukan penyandang autis akan tubuh dengan kesulitan-kesulitan seperti posisi duduk, posisi berdiri, kontrol tubuh saat bergerak dan perhatian pada indera (Widcaksana, 2019). 


\section{Penggambaran Autisme Dalam Film}

Dalam beberapa tahun ke belakang baik itu di dunia ataupun di Indonesia, masyarakat bisa melihat penggambaran orang dengan autisme melalui berbagai film. Beberapa di antaranya memberikan gambaran sesungguhnya terkait autisme, tentang bagaimana cara mereka berkomunikasi dan berinteraksi dengan orang lain. Akan tetapi tidak sedikit film-film bertema autisme dikritik karena melakukan penambahan drama berlebihan dan terkesan mengeksploitasi autisme itu sendiri. Salah satu film yang dikritik keras akan hal tersebut adalah The Accountant yang dirilis pada tahun 2016. Kebanyakan film dengan tema autisme dikrtik karena sering kali menunjukkan glorifikasi terhadap karakter penyandang autis yang dianggap sangat luar biasa cerdas dan memiliki nalar di luar kemampuan orang pada umumnya. Hal tersebut menjadikan pesan penting yang akan disampaikan melalui pesan tidak bisa tersampaikan dengan baik (Dhani, 2017).

Selain penggambaran karakter yang terlalu glorifikasi dengan kecerdasan dan kemampuan yang luar biasa cerdas, film-film bertemakan autisme seringkali menggambarkan karakter autis sebagai seseorang yang amat baik hati.

Penggambaran tersebut berbeda dengan fakta yang sesungguhnya di mana penyandang autis merupakan orang dengan masalah sensorik dan hipersensitif. Artinya mereka mudah untuk merasa tidak nyaman, sulit memahami kondisi, mudah emosi ketika tidak bisa menyampaikan sesuatu dan agresif (Wahyuningsih, 2012). Menurut para ahli emosi penyandang autis yang tidak terkendali bahkan dapat menyebabkan tindakan kekerasan. Hal tersebut sesuai dengan yang disampaikan oleh Mulyadi dalam Ralie (2018) bahwa anak dengan keterbelakangan autisme sulit dalam bersosialisasi dan menyampaikan perasaan ketidaknyamanan mereka sehingga lebih muda agresif dan mudah marah.

\section{Metodologi Penelitian}

Dalam penelitian ini paradigma yang akan digunakan adalah paradigma kritis. Alasan pemilihan paradigma kritis dikarenakan berkaitan pada penelitian yang akan dilakukan terkait 'Representasi Karakter Autis Dalam Film Dancing in The Rain' yaitu melihat dari adanya konstruksi sosial berupa stigma masyarakat terhadap para penyandang autis di mana salah satunya di pengaruhi oleh bagaimana cara media film merepresentasikan penyandang autis. Seperti halnya paradigma kritis yang digunakan pada permasalahan yang tidak luput dari keyakinan, ideologi atau keyakinan masyarakat umum, permasalah penyandang autis yang salah kini telah banyak menjadi keyakinan masyarakat.

Penggunaan paradigma kritis dalam penelitian ini sama halnya dengan sifat paradigma kritis sebagai paradigma yang berusaha membawa perubahan pada lingkungan sosial bermasyarakat, harapannya hasil dari penelitian ini dapat mengarahkan masyarakat pada stigma, kepercayaan dan ideologi yang benar terhadap penyandang autis.

Peneliti ingin mengkritisi bagaimana film Dancing in The Rain dalam menyampaikan pesan 
terkait penyandang autisme. Melihat dari adanya ketidak sesuaian antara harapan dengan kenyataan dalam penyampaian informasi pada film-film bertemakan autis yang sebelumnya pernah dibuat.

Penelitian ini menggunakan tipe penelitian kualitatif yang bersifat deskriptif. Menurut Creswell (2014) penelitian dengan tipe kualitatif merupakan penelitian dengan menggunakan metode-metode tertentu untuk mengeksplorasi dan lebih memahami makna individu atau kelompok yang memang dianggap sebagai permasalahan sosial atau kemanusiaan.

\section{Pembahasan}

\section{Mitos Dalam Film Dancing in The Rain}

\section{Sindrom Autis Tidak Bisa Disembuhkan}

Kurangnya pemahaman masyarakat Indonesia terkait autisme memunculkan stigma di masyarakat, tak jarang pula stigma yang salah memunculkan mitos-mitos tersendiri terkait sindrom autisme itu sendiri. Salah satu mitos yang beredar di masyarakat bahwa penyandang autis akan tetap dianggap sebagai penyandang autis sejak mendapat diagnose tersebut dan akan terus mengalami pola-pola autisme seumur hidupnya. Akan tetapi hal tersebut tidak sepenuhnya benar. Ada poin yang harus diluruskan.

Sindrom autisme tidak dapat disamakan dengan penyakit pada umumnya yang harus dinyatakan sembuh ketika tidak lagi mengalami tanda-tanda penyakit. Menurut hasil konfirmasi terapis autisme, sindrom autisme ibarat sebuah barang yang memiliki kekurangan pada komponen tertentu. Akan tetapi bukan berarti komponen tersebut akan kosong dan tidak ada selamanya. Di mana pada kasus sindrom autisme komponen tersebut dapat beruba kecacatan pada perilaku sosial, sikap ataupun perasaan. Seperti disampaikan terapis autisme Amelia dalam wawancara (20 Juni 2020) ada beberapa cara yang dapat dilakukan yaitu salah satunya dengan melakukan tindakan terapi untuk melengkapi komponenkomponen yang kosong tersebut agar penyandang autis dapat hidup normal seperti orang pada umumnya.

Hal tersebut juga terlihat pada beberapa scene dalam film Dancing in The Rain yang menampilkan bahwa sindrom autisme itu sendiri dialami oleh Banyu sebagai karakter utama selama hidupnya. Di mana tergambar dalam hasil analisis yang memperlihatkan pola pertumbuhan dan perkembangan Banyu saat mengalami autis pada masa kecil sampai dewasa.

Sejak kecil Banyu mulai mendapatkan treatment atau terapi, akan tetapi terlihat pula pada scene saat Banyu mengenakan seragam berwarna putih merah dengan logo tut wuri handayani yang mengindikasikan tingkat pendidikan sekolah dasar (Nugroho, 2019).

Akan tetapi terlihat ada perbedaan antara Banyu yang mengalami autisme saat ia masih berada di Taman Kanak-Kanak dengan Banyu yang berada di tingkat sekolah dasar dan 
mendapatkan terapi autisme. Terlihat dari Banyu yang mengalami perbaikan dari sisi bersosialisasi dengan anak sebayanya. Banyu bisa menjalin hubungan persahabatan dengan Kinara dan Radin.

Autisme yang dialami Banyu juga berlanjut sampai ia dewasa dan terlihat semakin membaik, terlihat pada scene saat Banyu sudah tumbuh besar dan terlihat bersiap untuk berangkat kuliah.

Dapat disimpulkan bahwa dari scenescene tersebut tergambarkan bahwa autisme yang dialami oleh Banyu berlangsung sejak ia kecil hingga dewasa. Akan tetapi sindrom autisme tersebut dapat diatasi dengan baik melalui treatment autisme yang Banyu jalani.

\section{Penyandang Autis Memiliki Fisik yang} Lemah, Tidak Berdaya dan Tidak Memiliki Kuasa Akan Dirinya Sendiri

Selain mitos terkait autisme yang tidak dapat disembuhkan, mitos lain yang seringkali ada di masyarakat yaitu penyandang autis yang lemah, tidak berdaya dan tidak memiliki kuasa akan dirinya sendiri. Menurut Amelia seorang terapis autism dalam wawancara (20 Juni 2020) hal tersebut sepenuhnya tidak dapat dibenarkan. Dalam hal fisik penyandang autis rata-rata mempunyai kekuatan lebih pada fisik, jika dibandingkan manusia normal pada umumnya.

Akan tetapi hal tersebut justru tidak diperlihatkan pada film Dancing in The Rain sering kali diperlihatkan scene-scene yang menggambarkan bagaimana penyandang autis lemah dari segi fisik. Seperti pada scene yamg memperlihatkan Banyu yang tengah diikatkan tali sepatunya oleh Eyang Uti.

Kemudian diperlihatkan melalui adegan perundungan dan diskriminasi. Seperti pada scene saat Banyu mendapatkan perundungan dari anak-anak lainnya saat bermain di luar rumah. Kemudian memicu tantrum Banyu, terlihat dari echolalia kata "Sakit, sakit, sakit" yang diucapkan secara terus menerus dan sikap menyakiti diri sendiri dengan memukulmukul kepala (Desiningrum, 2016). Pada scene ini Banyu terlihat lemah dan tidak berdaya, bahkan tidak membalas atau membela dirinya yang mengalami perundungan (Beritagar, 2019).

Hal tersebut amat memperlihatkan mitos bahwa penyandang autis memiliki fisik yang lemah sampai tidak bisa membela dirinya sendiri saat mengalami perundungan. Pada beberapa scene juga amat memperlihatkan mitos tersebut dengan menggambarkan Banyu sebagai penyandang autis yang tidak memiliki kuasa akan dirinya sendiri.

Seperti pada salah satu scene yang m e m perlihatkan baga imana ketidakberdayaan Banyu untuk membela dirinya sendiri saat mengalami kesalahpahaman dengan masyarakat. Sedangkan menurut Amelia sebagai terapis autisme dalam wawancara (20 Juni 2020) penyandang autisme bukannya tidak memiliki kuasa akan dirinya sendiri, akan tetapi seringkali masyarakat, keluarga dan lingkungan sekitar tidak memberikan kesempatan bagi penyandang autis untuk 
berkuasa dan membela dirinya sendiri. Dikarenakan seringkali penyandang autis diperlakukan tidak bisa membela atupun mengurus dirinya sendiri.

Selain itu Amelia sebagai terapis autis juga memaparkan dan mengkonfirmasi bahwa memang penyandang autis dari sisi psikologis dapat dipandang berbeda dengan orang normal pada umumnya. Hal tersebut juga diperlihatkan pada adegan dalam film.

Maka dari scene-scene tersebut terlihat dengan jelas bagaimana penggambaran Banyu sebagai penyandang autis dalam film tersebut yang tidak bisa membela dirinya sendiri dan terlihat sebagai tokoh yang lemah. Sering kali penggambaran tersebut diperlihatkan melalui adegan diskriminasi dan perundungan. Penggambaran tersebut tidak jauh berbeda dengan film-film yang juga bertema terkait autis lannya. Hal tersebut berdampak pada mitos terkait kondisi penyandang autis di masyarakat yang seringkali dianggap dan diperlakukan sebagai seseorang yang lemah, tidak berdaya dan tidak memiliki kuasa akan dirinya sendiri.

\section{Penyandang Autis Tidak Dapat Mandiri} dalam Kehidupan Sehari-Hari

Mitos lainnya yang beredar di masyarakat dan masih tergambar dalam film Dancing in The Rain yaitu bahwa penyandang autis juga terlihat tidak mandiri dalam kehidupan sehari-harinya. Sering kali pada beberapa scene dalam film diperlihatkan Banyu dibantu oleh karakter-karakter dominan dalam film. Bahkan sikap tidak mandiri tersebut sudah terlihat sejak karakter masih berusia anakanak.

Di mana penggambaran tersebut sangat dianggap keliru oleh terapis autisme. Menurut Amelia sebagai terapis autism dalam wawancara (20 Juni 2020), sindrom autisme itu bersifat spektrum sehingga akan menampilkan kekhasan, keunikan dan perbedaan antara satu penyandang autis dengan penyandang autis lainnya. Sehingga pemahaman bahwa penyandang autis itu tidak dapat mandiri dalam hidupnya tidak dapat di generalisasikan kepada penyandang autis secara keseluruhan.

Menurutnya karakter Banyu yang digambarkan sebagai penyandang sindrom Asperger menjadi alasan mengapa Banyu digambarkan sebagai penyandang autis yang kurang mandiri, dikarenakan ia memiliki kelebihan dari sisi kongnitif. Akan tetapi tetap saja hal tersebut merupakan mitos, dikarenakan presentase penyandang autis yang tidak dapat mandiri sangat kecil dibandingkan dengan penyandang autis yang dapat mandiri dalam hidupnya.

\section{Ketergantungan Penyandang Autis Pada} Orang Lain

Banyak masyarakat memandang penyandang autis sebagai orang yang bergantung pada orang lain, terutama pada keluarga atau pengasuh. Menurut Amelia terapis autisme dalam wawancara (20 Juni 
2020), hal tersebut sama sekali bukanlah hal yang dapat dibenarkan atau bisa disebut sebagai mitos.

Hal tersebut juga diperlihatkan dalam film Dancing in The Rain melalui adegan Banyu mengambil keputusan untuk mendonorkan jantungnya kepada Radin. Dari scene tersebut dapat terlihat bagaimana Banyu mengambil ke putusannya sendiri tan pa mempertimbangkannya dengan orang lain. Hal tersebut membuktikan bahwa ia tidak bergantung pada orang lain dalam mengambil keputusan tersebut.

Menurut penelitian yang dilakukan oleh Kusumasar (2018) menyatakan bahwa terdapat beberapa cara atau bentuk terapi yang dapat dilakukan pada penyandang autis untuk meningkatkan kemandirian mereka. Salah satunya adalah program AKS (Aktivitas Kehidupan Sehari Hari).

Pada hasil penelitian Kusumasar tersebut membuktikan bahwa kemandirian penyandang autis dapat meningkat setelah mendapatkan terapi yang dibantu oleh dukungan keluarga dan lingkungan sekitar. Hal tersebut juga diperlihatkan dalam film Dancing in The Rain, di mana Banyu mengalami peningkatan kemandirian setelah mendapatkan terapi.

Diperlihatkan dari adegan di mana ia bisa mempersiapkan dirinya sendiri, mengikat tali sepatunya sendiri saat dewasa dan bisa berangkat berkuliah seorang diri tanpa harus ditemani ataupun dibantu oleh orang lain. Terdapat juga adegan yang memperlihatkan Banyu yang mengikuti olimpiade tanpa didampingi oleh anggota keluarga, rekan ataupun sahabat. Menunjukkan bahwa ia sudah mengalami peningkatan dalam hal kemandirian setelah mendapatkan terapi.

\section{Penyandang Autis Memiliki Keunikan Pada Fisik dan Tidak Memiliki Perasaan Atau Sisi Emosional yang Berlangsung Seumur Hidup}

Kurangnya pehaman terkait autisme seringkali membawa pemahaman yang salah terkait autisme. Salah satunya adalah kesalahan masyarakat yang sering kali menyamakan ciri autisme dengan down syndrome. Di mana jelas sekali bahwa penyandang autis dan penyandang down syndrome itu berbeda. Akan tetapi jika melihat dari bagaimana film Dancing in The Rain merepresentasikan penyandang autis baik itu dari fisik, perilaku dan perasaan terdapat beberapa hal yang memang sesuai dengan fakta yang ada.

Menurut Amelia sebagai terapis autism dalam wawancara (20 Juni 2020), bahwa autisme tidak memiliki ciri khas pada fisik, jika dalam fisik yang dimaksud merupakan bentuk wajah tertentu. Hal tersebut juga digambarkan dalam film Dancing in The Rain di mana Banyu tidak memiliki kekhasan pada ciri wajah tertentu yang terlihat membedakan ia dengan laki-laki normal. Akan tetapi jika dikaitkan pada ciri fisik melalui postur tertentu pada tangan, punggung dan bagian tubuh tertentu, penyandang autis memang memiliki kekhasan pada hal tersebut.

Seperti dalam beberapa adegan kekhasan fisik Banyu juga terlihat dalam film seperti 
memiringkan kepala dan membungkukkan badan. Keunikan pada fisik tersebut berlangsung sejak ia kecil hingga ia dewasa. Hal tersebut memberikan gambaran penyandang autis yang seringkali ditemukan memiliki kekurangan pada postur tubuh. Selain postur tubuh penyandang autis juga sering kali memiliki gangguan pada fisik, termasuk di dalamnya terkait mobilitas, keterampilan motorik ataupun kekuatan otot (Widcaksana, 2019).

Maka dapat disimpulkan bahwa penyandang autis tidak memiliki ciri fisik tertentu seperti anggapan masyarakat yang memahami autisme sama dengan down syndrome. Akan tetapi bukan berarti penyandang autis memiliki sifat yang sama pula dengan orang normal. Karena penyandang autis memiliki keunikan pada sikap seperti menggerakan tubuh kedepan dan kebelakang (rocking), mengepakngepakan tangan (flapping) dan menggerakkan kaki (Desiningrum, 2016).

Selain mitos terkait fisik, mitos lain yang menghantui para penyandang autis adalah bahwa mereka merupakan orang-orang dengan keterbelakangan emosional bahkan dianggap tidak memiliki sisi emosional. Pada dasarnya penyandang autis bukanlah seseorang yang tidak memiliki emosional, akan tetapi mereka sering kali memiliki kesulitan dalam mengendalikan emosi (Ralie, 2018).

Menurut Amelia dalam wawancara (20 Juni 2020) justru penyandang autis memiliki kepekaan/ sensitifitas yang lebih baik dibandingkan orang pada umumnya, tertuma jika hal tersebut menyangkut pada orangorang terdekatnya. Hal tersebut juga tergambarkan dalam film Dancing in The Rain bahwa Banyu sebagai penyandang autis memiliki sisi emosional. Seperti saat karakter Banyu dalam film yang memiliki sifat ataupun kepekaan untuk membantu orang lain.

Kemudian pada scene saat Radin tiba-tiba mengalami serangan jantung, Banyu terlihat begitu khawatir dan panik saat berada dalam mobil ambulans dan terlihat Banyu yang bersedih akibat kondisi yang Radin alami. Hingga puncaknya Banyu mendonorkan jantungan pada Radin agar Radin bisa sembuh kembali.

6. Penyandang Autis Tidak Bisa Berprestasi Karena Tidak Memiliki Kelebihan

Dalam film Dancing in The Rain juga telihat penggambaran karakter penyandang autis yang berbeda dari stigma masyarakat. Di mana penyandang autis sering kali dianggap sebagai seseorang yang idiot, bodoh ataupun tidak cerdas (Kompas, 2019).

Menurut Amelia dalam wawancara (20 Juni 2020) pandangan penyandang autis tidak bisa berprestasi merupakan hal yang salah atau mitos tersebut juga dikoreksi melalui film Dancing in The Rain. Di mana karakter Banyu sebagai penyandang autis, digambarkan sebagai seseorang yang memiliki kelebihan. Banyu yang sudah mendapatkan treatment 
sejak kecil akhirnya menemukan fokus bakat terpendam dalam menggambar. Dapat terlihat pada beberapa scene-scene awal di mana Banyu sangat fokus pada dunianya sendiri yaitu menggambar, sampai-sampai ia mengabaikan lingkungan sekitar.

Setelah mendapatkan treatment bakat tersebut dikembangkan, seperti terlihat pada scene di mana Banyu memiliki banyak sekali hasil karya gambar baik itu di buku ataupun yang ditempelkan pada dinding kamarnya. Selain itu pada saat Banyu sudah dewasa terlihat bagaimana Banyu tumbuh menjadi seseorang yang berprestasi. Di mana terlihat pada salah adegan terlihat banyaknya piala dan piagam penghargaan yang Banyu dapatkan ditata rapih di atas lemari.

Kemudian pada scene selanjutnya saat Banyu dan Eyang Uti berada di kamar Banyu, terlihat pada dinding kamar Banyu berhiaskan piagam penghargaan. Pada scene lainnya juga memperlihatkan bakat Banyu dalam bermain rubik hanya dengan satu tangan. Di mana hal tersebut tidak umum bisa dilakukan oleh semua orang. Bahkan bakat dan kejeniusan Banyu ditayangkan dalam sebuah tayangan televisi.

Pada scene akhir memperlihatkan tayangan berita yang menayangkan pemberitaan tentang kejeniusan dan kebaikan Banyu. Maka scene-scene tersebut memperlihatkan bagaimana Banyu sebagai penyandang autis memiliki kelebihan dan bakat tidak seperti stigma dan mitos yang beredar di masyarakat. Bahkan Banyu dapat mendapatkan begitu banyak piala dan piagam penghargaan akan bakatnya.

\section{Diskusi Teoritik}

Penggambaran karakter penyandang autis dalam sebuah film sebagai media pembelajaran untuk menanggulangi stigmatisasi, perundungan dan diskriminasi pada penyandang autis menjadi pembahasan penting dalam penelitian ini.

Di mana sering kali masyarakat memberikan stigma-stigma tertentu kepada para penyadang autis seperti autisme sama dengan idiot atau penyakit kejiwaan (orang gila), sama dengan down syndrome, atau autisme tidak memiliki sisi emosional dan lain sebagainya.

Munculnya pemahaman-pemahaman tersebut tentunya berasal dari peran banyak pihak dalam memberikan informasi dan merepresentasikan penyandang autis, salah satunya adalah peran dunia perfilman. Seperti film Dancing in The Rain yang tayang pada tahun 2018 menjadi film terbaru di Indonesia yang membahas terkait penyandang autis. Walaupun memang bukan menjadi film Indonesia satu-satunya yang membahas terkait autisme, film Dancing in The Rain seharusnya dapat memberikan gambaran baru terkait kondisi penyandang autis di Indonesia terutama dalam segi perkembangan sosial penyandang autis.

Pada tahun-tahun sebelumnya terdapat beberapa karya film Indonesia yang membahas terkait penyandang autisme. Seperti film My Idiot Brother, Malaikat Kecil, 
I'm Star dan lain sebagainya. Jika ditarik lurus persamaan antara film-film tersebut dapat dilihat bahwa penggambaran karakter penyandang autis dalam film tersebut digambarkan dengan begitu positif atau bahkan terlalu positif. Hal tersebut diperlihatkan pada setiap karakter penyandang autis baik itu pada sikap ataupun perilaku.

Glorifikasi, over positive dan eksploitasi karakter secara berlebihan menjadi kritikan keras yang sering kali dilontarkan untuk filmfilm dengan tema autisme. Seringkali hal tersebut menutupi pesan penting yang ingin disampaikan melalui film tersebut. Hal tersebut juga masih terlihat dalam film Dancing in The Rain. Di mana dalam film tersebut memberikan representasi yang menggambarkan penyandang autis begitu baik hati bak malaikat.

Penggambaran karakter tersebut pada kenyatannya sangat bertolak belakang dengan stigma masyarakat terkait penyandang autis yang tidak memiliki sisi emosional. Akan tetapi penggambaran karakter baik hati tersebut terkesan berlebihan memperlihatkan Banyu sebagai penyandang autis rela memberikan jantungnya pada sahabatnya. Selain itu kesan penggambaran karakter baik hati yang berlebihan juga terlihat dari sikap dan tindakan karakter Banyu saat mendapatkan perundungan dan diskriminasi, di mana karakter terlihat begitu lemah, tidak berdaya dan tidak memiliki kuasa untuk membela dirinya sendiri. Sisi glorifikasi dan eksploitasi sudut karakter yang terlalu berlebihan ini sering kali terlewatkan pada analisis terkait representasi karakter autis dalam sebuah film.

Banyu sebagai penyandang autis dalam film ini juga sering kali digambarkan sebagai penyandang autis yang tidak mandiri dalam kehidupannya sehari-hari. Dalam banyak adegan sering kali Banyu diperlihatkan sebagai karakter yang begitu bergantung pada orang lain. Seperti pada adegan saat Banyu bersinggungan dengan orang lain ia tidak bisa membela dirinya dan karakter dominan dalam film yang menjadi sosok penolong dan pembela untuk membantu.

Akan tetapi jika melihat dari alur cerita sebetulnya film Dancing in The Rain memperlihatkan bagaimana Banyu mendapatkan treatment sebagai penyandang autis.

Sebagai karakter penyandang autis memang diperlihatkan bagaimana Banyu mengalami diskriminasi dan dikucilkan dari lingkungannya terutama saat ia masih kecil. Akan tetapi treatment yang dilakukan Banyu memperlihatkan dampak perubahan pada sikap atau kepekaannya terhadap lingkungan sosial.

Terlihat dari Banyu yang memiliki Radin dan Kinara sebagai sahabatnya sejak kecil hingga ia dewasa. Di mana kebaruan dan kontribusi dalam penelitian ini menunjukkan bagaimana penyandang autis dapat menjalin persahabat yang normal dan hal tersebut belum pernah tergambarkan pada film 
Indonesia lainnya yang mengangkat tema serupa. Dengan demikian penelitian ini mengkonfirmasi mitos yang ada di masyarakat bahwa penyandang autis tidak bisa berkembang dari segi aspek sosial. Namun karakter dalam film menunjukkan progres aspek sosial yang positif setelah mendapatkan terapi atau treatment.

Dampak dari treatment tersebut juga mengarahkan Banyu untuk dapat memiliki minat pada bidang kecerdasan dan menggambar yang membawanya menghasilkan banyak prestasi lebih dari manusia normal pada umumnya. Terlihat d a l a m beberapa a degan yang memperlihatkan piala, piagam dan keahlian Banyu dalam bidang sains ataupun menggambar. Walaupun sekali lagi dalam film terlihat eksploitasi karakter Banyu sebagai penyandang autis yang jenius terlihat berlebihan. Hal tersebut dapat berdampak pada pembentukan stigma bahwa penyandang autis merupakan orang-orang jenius.

Seperti apa yang disampaikan oleh penulis Tisa TS bahwasanya film ini ingin menyampaikan pesan bahwa kita dikelilingi oleh orang-orang yang tidak sempurna dan bagaimana kita harus menghargai ketidaksempurnaan tersebut dengan membagikan kebahagiaan pada orang lain. Walaupun memang masih banyak hal yang perlu diperhatikan dalam menggambarkan karakter penyandang autis terlebih lagi soal penggambaran over positive pada karakter. Akan tetapi film Dancing in The Rain memberikan kebaruan akan representasi karakter penyandang autis dibandingkan filmfilm sebelumnya melalui alur cerita drama persahabatan.

\section{Kesimpulan}

Tujuan utama penelitian ini adalah untuk menjelaskan representasi karakter autis dalam film Dancing in The Rain. Sementara secara keseluruhan, hasil penelitian ini memberikan pemahaman mendalam dengan metode semiotik, berupaya mendeskripsikan tanda-tanda denotatif, konotatif dan mitos yang ditampilkan dalam sejumlah scene di film Dancing in The Rain, untuk menjelaskan karakter penyandang autis.

Penelitian terkait pengambaran karakter autis dengan menampilkan perkembangan karakter dari masa kecil sampai dengan masa remaja di film Indonesia masih sangat sedikit dan jarang dilakukan. Terlebih bila dikaitkan dengan area studi terkait persuasi narasi dan kajian media (film), sehingga diharapkan penelitian ini memberikan kontribusi sesuatu yang baru.

Hasil penelitian menunjukkan bahwa film Dancing in The Rain masih menempatkan karakter penyandang autis sebagai kaum yang termarjinalkan. Film ini masih menggunakan dominasi dan keterlibatan karakter lain untuk mengontrol karakter autis. Dalam film ini autis ditampilkan sebagai kalangan disabilitas yang dijadikan objek untuk menarik simpati penonton. Secara umum, karakter autis dalam film ini ditampilkan di satu sisi secara 
overpositive, digambarkan sebagai individu yang cerdas, gigih dan menjadi pahlawan bagi sekitarnya. Sementara disisi lain ditampilkan sebagai individu yang tidak berdaya dan tidak memiliki kuasa atas dirinya.

Temuan dan interpretasi data penelitian dari sekitar 28 scene dalam film Dancing in The Rain yang di analisis, menghasilkan sejumlah mitos dan temuan menarik. Temuan menarik yang berhasil ditangkap melalui penggambaran karakter Banyu sebagai penyandang autis. Salah satunya, alur pada film yang menggambarkan fokus terkait perkembangan sosial yang coba diangkat sebagai manfaat dari treatment atau terapi yang dijalani sejak dini pada penyandang autis. Hal tersebut memberikan pemahaman penanganan autisme sejak dini dan baik untuk anak yang bisa berdampak pada banyak hal untuk menunjang masa depan penyandang autis. Diperlihatkan mulai dari dampak kognitif, motorik dan perkembangan kehidupan sosial.

Kemudian dari sisi lainnya film Dancing in The Rain juga memberikan gambaran kebaruan terkait penggambaran karakter autis dalam lingkungan sosial. Di mana stigma masyarakat seringkali menganggap penyandang autis tidak dapat bersosialisasi atau menjalin hubungan dengan orang lain. Dalam film digambarkan bahwa Banyu sebagai penyandang autis yang mendapatkan treatment atau terapi mengalami proses perubahan ke arah yang lebih baik dalam hal kehidupan sosial dan dapat memiliki hubungan persahabatan sejak kecil dengan anak normal lainnya. Bahkan persahabatan tersebut berjalan hingga Banyu dewasa.

Pada sejumlah adegan dalam film yang berupaya menggambarkan kecerdasan yang dimiliki karakter Banyu, seakan berupaya mematahkan stigma bahwa penyandang autis tidak cerdas. Banyu digambarkan memiliki kecerdasan secara kognitif, ditampilkan dengan berhasilnya Banyu untuk memasuki jenjang pendidikan sampai dengan perkuliahan bahkan menjadi juara Olimpiade Sains.

Disamping kecerdasan kognitif, Banyu juga digambarkan memiliki kelebihan dalam hal menggambar atau melukis, ditampilkan melalui berbagai macam prestasi yang diraih, untuk mematahkan stigma bahwa penyandang autis tidak memiliki kematangan terutama terkait masa depan.

\section{DAFTAR PUSTAKA}

Ardianto. (2012). Komunikasi Massa: Suatu Pengantar. Bandung: Simbiosa Rekatama Media.

Auticare.id. (2019). Apakah Anak Autis Bisa Sembuh? Diakses pada 22 Februari 2020 dari: https://auticare.id/apakah-anakautis-bisa-sembuh/

Autismerupe.org. (2019). People with Autism Spectrum Disorder Third Edition. Diakses pada 8 Februari 2020 dari: https://www.autismeurope.org/wpcontent/uploads/2019/09/People-withAutism-Spectrum-Disorder-IdentificationUnderstanding-Intervention_compr essed.pdf.pdf 
Avrila, T. (2019). Analisis Semiotika Pesan Dakwah Dalam Film Keluarga Cemara Tahun 2019. (Skripsi untuk Jurusan Komunikasi dan Penyiaran Islam, Fakultas Ushuluddin Adab dan Dakwah di Institut Agama Islam Negeri Tulungagung. Diakses dari: http://repo.iaintulungagung.ac.id/12871/1/COVER.pdf Diakses pada 19 Februari 2020

Chodidjah, S dan Kusumasari, AP. (2018). Pengalaman Ibu Merawat Anak Usia Sekolah Dengan Autis. (Jurnal Keperawatan Indonesia, Volume 21 No.2, Juli 2018, Hal 94-100 pISSN 1410-4490, Eissn 2354-9203 DOI: 10.7454/jki.v2li2.545). Diakses dari https://media.neliti.com/media/publications /272600-none-a3c83116.pdf Diakses pada 28 April 2020

Creswell, J. W. (2014). Research Design: Qualitative, Quantitative and Mixed Methods Approaches (4th ed.). Thousand Oaks. CA: Sage.

Dhani, A. (2017). Memahami Autisme Lewat Film. Titrto.id. Diakses pada 21 Maret 2020, dari https://tirto.id/memahami-autisme-lewatfilm-clYq.

Desiningrum, DR. (2016). Psikologi Anak Berkebutuhan Khusus. Yogyakarta: Psikosain

Eka, M. (2013). Sinopsis Film 'I'm Star' yang Dibintangi Anak-Anak Autis. Diakses pada 8 Februari 2020. Kapanlagi.com. Diakses dari: https://www.kapanlagi.com/ showbiz/film/indonesia/sinopsis-film-ima-star-yang-dibintang-anak-anak-autis7a64e8.html

Forno, DM. (2015). Penggambaran Karakter Pada Tokoh Utama dalam Dilm "Meleficent". Surabaya: Program Studi IImu Komunikasi, Universitas Kristen Petra Surabaya.
Ghassani, A. (2019). Pemaknaan Rasisme Dalam Film (Analisis Resepsi Film Get Out). Jurnal Manajemen Maranatha Volume 18, Nomor 2. Diakses dari https://journal.maranatha. edu/index.php/jmm/article/view/1619/12 60 Diakses pada pada 22 Maret 2020.

Hardian, NL. (2018). 6 Film Indonesia ini Mengangkat Tema Autis Kisahnya Bikin Haru. Brilio.net. Diakses pada 21 Maret 2020, dari https://www.brilio.net/film/6film-indonesia-ini-mengangkat-tema-autiskisahnya-bikin-haru-181129o.html

Hasanah, IM. (2019). Analisis Karakter Tokoh Film "Pada Zaman Dahulu" Episode Jangan Bersahabat Dengan Kera Di MNCTV. (Skripsi untuk Fakultas Dakwah dan Komunikasi di Universitas Islam Negeri Walisongo). Diunduh dari http://eprints.walisongo .ac.id/10018/1/Skripsi\%20Full\%20w ord.pd f, Diakses pada 13 Februari 2020.

Hosnan. (2014). Pendekatan Saintifik dan Konstektual dalam Pembelajaran Abad 21. Kunci Sukses Implementasi Kurikulum 2013. Jawa Barat: Ghalia Indonesia.

Irfandy, MN. (2019). Komunikasi Kepemimpinan Dalam Film Moneyball (Analisis Semiotika Model Roland Barthes). (Skripsi untuk Program Studi IImu Komunikasi, Fakultas Dakwah dan Komunikasi di Universitas Islam Negeri Sunan Ampel Surabaya). Diakses dari Diakses pada 19 Februari 2020,

Kemenpppa.go.id. (2018). Hari Peduli Autisme Sedunia: Kenali Gejalanya, Pahami Keadaannya. Diakses pada 8 Februari 2020. Diakses dari: https://www.kemenpppa. go.id/index.php/page/read/31/1682/haripeduli-autisme-sedunia-kenali-gejalanyapahami-keadaannya 
Kompas.com. (2019). Mitos-mitos yang Banyak Beredar Seputar Anak Autis dan Kebenarannya. Diakses pada 28 April 2020, dari https://lifestyle.kompas. $\mathrm{com} / \mathrm{read} / 2019 / 08 / 24 / 112234620 /$ mitosmitos-yang-banyak-beredar-seputar-anakautis-dan-kebenarannya?page=all

Kurniadi, G dan Soetikno, A. (2019). Hubungan Antara Harapan dan Stres Orang Tua Yang Memiliki Anak Dengan Autisme. Jakarta: Universitas Tarumanegara.

Kirnandita, P. (2017). Cukup Sudah Merundung Pengidap Autisme. Tirtro.id. Diakses pada 28 April 2020, dari https://tirto.id/cukupsudah-merundung-pengidap-autisme-cl1L

Muthmainah, NA. (2020). Penokohan Film Joker Karya Todd Phillips (Analisis Resepsi Tokoh Arthur Fleck Oleh Anak Muda Usia 18-24 Tahun di Jakarta Selatan). (Skripsi untuk Program Studi Komunikasi, Fakultas Komunikasi dan Diplomasi di Universitas Pertamina). Diakses dari Diakses pada 25 Februari 2020.

Nugroho, RA. (2019). Jarang Diperhatikan, ini Filosofi Seragam Sekolah yang Perlu Kamu Ketahui. Hot Liputan6. Diakses pada 28 April 2020, dari https://hot.liputan6.com/read/ 3943779/jarang-diperhatikan-ini-filosofiseragam-sekolah-yang-perlu-kamu-ketahui

Permatasari, I dan Yenny. (2019). Budaya Populer: Representasi Dalam Film "My Generation" Karya Upi Aviyanto. Surabaya: Universitas dr. Soetomo Surabaya.

Putra, AE. (2019). Representasi Kemiskinan Perkotaan Pada Film Dokumenter Jakarta Unfair (Analisis Semiotika Roland Barthes). (Skripsi untuk Program Studi IImu Komunikasi, Fakultas IImu Komunikasi di Universitas Multimedia Nusantara). Diakses dari dari http://kc.umn.ac.id/10901/ Diakses pada 19 Februari 2020

Putri, MK. (2018). Representasi Simbol Gay Dalam Film. (Skripsi untuk Jurusan IImu Komunikasi, Fakultas IImu Sosial dan Politik di Universitas Muhammadiyah Malang). Diakses pada 19 Februari 2020, dari: https://onesearch.id/Record/IOS4109.4268 4Ralie, Z. (2018). Hubungan Autisme, Agresivitas, dan Kekerasan. Beritagar.id. Diakses pada 21 Maret 2020, dari https://beritagar.id/artikel/gayahidup/hubungan-autisme-agresivitas-dankekerasan

Rochmawati, WP. (2016). Analisis Nilai-Nilai Pendidikan Karakter Dalam Film "The Miracle Worker". (Skripsi untuk Fakultas Ilmu Tarbiyah dan Keguruan di Universitas Islam Negeri Maulana Malik Ibrahim Malang). Diakses dari http://etheses.uinmalang.ac.id/3474/ Diakses pada 29 Februari 2020

Sanni, MI, dan Ramdhan, D. (2016). Pemanfaatan Angle Fotografi Pada Foto Dokumentasi. Jurnal ISSN: 2356-5209 Vol. 2 No.01 Jakarta: STIM LPMI Jakarta.

Saragih, BH. (2019). Representasi Androgini Celebrity Endorser Dalam Media Sosial Instagram. (Skripsi untuk Departemen IImu Komunikasi, Fakultas IImu Sosial dan IImu Politik di Universitas Sumatera Utara. D i a k e s d a r i : http://repositori.usu.ac.id/bitstream /handle/123456789/13340/140904067.pd f?sequence=1\&isAllowed $=y$ Diakses pada 19 Februari 2020

Sekhu, A. (2018). Film Dancing in The Rain Beri Pesan Ketidak Sempurnaan. Cendana News. Diakses pada 4 Februari 2020. Diakses dari: https://www.cendananews.com/2018/10/ film-dancing-in-the-rain-beri-pesanketidaksempurnaan.html 
Sihombing, EC. (2019). Penyandang Autisme di Indonesia Masih Mengalami Diskriminasi. Diakses pada 8 Februari 2020. Beritasatu. Diakses dari https://www.beritasatu.com/ kesehatan/546709/penyandang-autismedi-indonesia-masih-mengalamidiskriminasi

Toni, A. (2015). Peran Film Sebagai Media Sosialisasi Lingkungan. Jakarta: Universitas BudiLuhur.

Ultimagz.com. (2019). Mengenal Peran Media dan Disabilitas Bersama Remotivi dan JBFT. Diakes pada 4 Februari 2019. Diakses dari: https://ultimagz.com/event/mengenalperan-media-dan-disabilitas-bersamaremotivi-dan-jbft/

Wahyudi, I. (2018). Forkasi Apresiasi Film Dancing in The Rain? Bali Antaranews. Diakses pada 9 Februari 2020. Diakses dari: https://bali.antaranews.com/nasional/berit a/760436/forkasi-apresiasi-film-dancing-inthe-rain? utm_source=antaranews \&utm_medium=nasional\&utm_campaign= antaranews

Wahyuningsih, M. (2012). Saat Anak Autis Marah, Bisakah Picu Kekerasan? Detik.com. Diakses pada 21 Maret 2020, dari https://health .detik.com/ulasan-khas/d-2122330/saatanak-autis-marah-bisakah-picu-kekerasan

Widcaksana, HS. (2019). Apa Saja Peran Seorang Terapis Fisik Untuk Anak Autis? Auticare.id. Diakses pada 12 Maret 2020, dari https:// auticare.id/apa-saja-peran-seorang-terapisfisik-untuk-anak-autis/

Wijayanti, S. (2019). Yuk Belajar Memahami Penyandang Autis dan Keluarganya. Brilio.net. Diakses pada 8 Februari 2020. D i a k s e s d a $r$ i : https://www.brilio.net/creator/yuk-belajar- memahami-penyandang-autis-dankeluarganya-6c0833.html

World Health Organization. 2019. Autism Spectrum Disorders. Diakses pada 8 Februari 2020. Diakses dari https://www.who.int /news-room/fact-sheets/detail/autismspectrum-disorders 